\author{
Martin Vicen $\bowtie$ \\ Jozef Bronček \\ Otakar Bokùvka \\ Ružica Nikolić \\ Norbert Radek
}

https://doi.org/10.21278/TOF.452019320

ISSN 1333-1124

eISSN 1849-1391

\title{
TRIBOLOGICAL BEHAVIOUR OF THE SUCASLIDE DIAMOND-LIKE CARBON COATING
}

\section{Summary}

Tribological behaviour of the Sucaslide diamond-like carbon coating applied to lowalloy steel was studied in this research. Experimental work included the determination of the chemical composition and the evaluation of the microstructure of both the base material and the Sucaslide coating. The methods used in the research were dilatometry and energy dispersive x-ray analysis, mechanical properties measurements, and wear resistance and scratch tests. From the results obtained in experiments, the authors concluded that the Sucaslide DLC coating has very good sliding and abrasion-resistant properties. With regard to these facts, it is possible to recommend the Sucaslide DLC coating for application to the lowalloy steel used in the bearing industry.

Key words: $\quad$ Sucaslide diamond-like carbon coating, low-alloy steel, tribological behaviour, useful properties.

\section{Introduction}

Increasing demands on the operation of equipment are forcing technologists and designers to develop new techniques for the surface treatment of structural materials. Different procedures and methods are used to reduce wear of functional surfaces of components (Fig. 1) and to improve their mechanical and tribological properties.

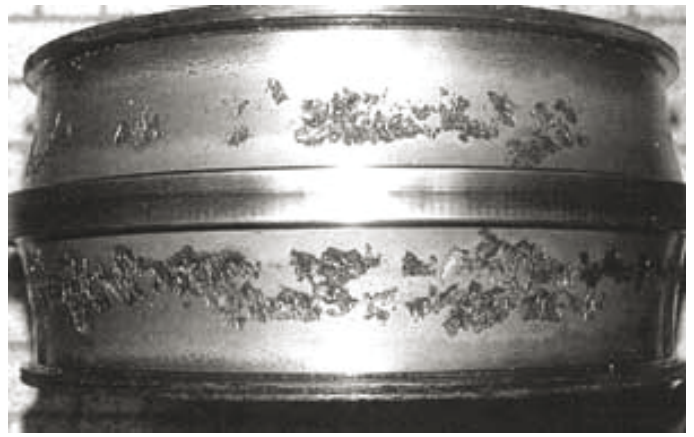

(a)

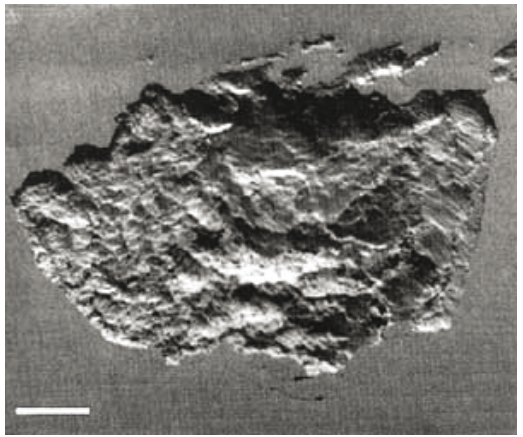

(b)

Fig. 1 Bearing ring wear caused by materials in contact: a) fatigue spalls on the outer bearing race, b) spall crater - detail [1] 
Surface treatment of structural materials is currently carried out by the PhysicalVapour-Deposition (PDV) and Chemical-Vapour-Deposition (CVD) technologies, which allow the creation of a wide range of thin coatings. The coatings formed by these technologies generally possess excellent mechanical, tribological, chemical, and electrical properties. They improve the quality, performance, reliability and durability of industrial products $[2,3]$. Extending the service life of products is of a great importance, both from the economic and environmental points of view.

In industrial practice, combinations of very hard layers and sliding layers, which are also the functional surfaces, are primarily being developed. Simultaneously, technologies for the mechanical treatment of the base material (substrate) before and after coating are being developed with the aim to significantly improve the properties of industrial products [4]. Among a large number of coatings are the so-called Diamond-Like Carbon (DLC) coatings, intended mainly for tribological joints (pairs) operating in both dry and lubricated conditions. An important factor is the adhesion of the coating to the base material (substrate). Mechanical properties, thermal resistance and chemical resistance, low values of the coefficient of friction, low application temperatures, and a possibility of not using lubricating fluids in the systems are investigated. Some lubricant additives exhibit undesirable compatibility with DLC coatings [5, 6]. An important type of DLC coatings is the Super-Carbon-Slide (Sucaslide) coating, which is prepared in the form of a diamond carbon matrix characterized by high hardness, good wear resistance, low coefficient of friction, chemical inertness, and biocompatibility [7, 8]; these properties qualify Sucaslide for wide application in the bearing industry, for coatings resistant to degrading corrosion processes and as protective coatings for cutting tools and gears [9-14].

The objective of this study was to experimentally verify the tribological behaviour of the Sucaslide DLC coating applied to low-alloy steel.

\section{Experiment}

Experimental work was focused on determining the tribological properties of the Sucaslide DLC coating. The base material to which the coating was applied was low-alloy stainless steel used in the bearing industry. This steel, used in the aforementioned applications, was obtained in the form of $\varnothing 60 \mathrm{~mm}$ bars, in the soft annealed state. Verification of the chemical composition, and qualitative and quantitative chemical analyses were performed by a spark emission SPECTROMAXx. Test specimens (6 pieces) were prepared from the supplied material by chip machining; the shape and dimensions of specimens are shown in Fig. 2.

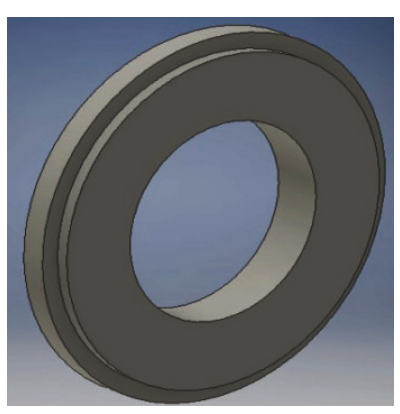

(a)

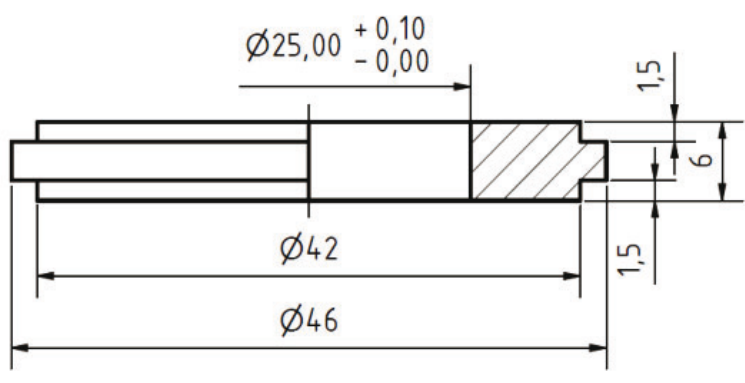

(b)

Fig. 2 Test specimen: a) a 3D model, b) dimensions of the specimen 
The test specimens were then heat-treated, austenitized at $840{ }^{\circ} \mathrm{C} \pm 5{ }^{\circ} \mathrm{C}$ for 20 minutes, cooled in oil to $20^{\circ} \mathrm{C} \pm 2{ }^{\circ} \mathrm{C}$, tempered at $160{ }^{\circ} \mathrm{C} \pm 5^{\circ} \mathrm{C}$ for 90 minutes, and finally cooled in the open air.

After the heat treatment, the microstructure was studied by a NEOPHOT 32 light microscope with the NIS Elements 4.20 evaluation system and by a VEGA TESCAN electron microscope. The residual austenite was determined by the dilatometric analysis performed on a PHILIPS PW 1710 device. Hardness of the test specimens was determined by the Rockwell hardness test (HRC) on an RR-1D / AQ tester. Minimum of 5 punctures were done on each specimen. The fronts of the test specimens before coating were ionically cleaned in order to remove impurities from their surface. The Sucaslide DLC coating was deposited on the surfaces of test specimens thus prepared.

The deposition of the Sucaslide coating was performed in a vacuum chamber for 6 hours, at a working pressure of 0.1 to $1 \mathrm{~Pa}$. The thickness of the Sucaslide coating was measured by the Calotest method; it was from 1.5 to $2 \mu \mathrm{m}$. The dry friction coefficient of the Sucaslide DLC coating was experimentally determined on a T-01M tester by the Ball-on-Disc test method [15]. Two tribological pairs were tested: the base material versus the Sucaslide DLC coating (referred to as a "Sucaslide pair") and a reference pair, the base material versus the base material (referred to as a "Reference pair").

The test duration $(\mathrm{t})$ was $5400 \mathrm{~s}$ (the path length of the specimen was approximately $4320 \mathrm{~m}$ at a specimen rotation speed $(\mathrm{v})$ of $\left.0.8 \mathrm{~m} \cdot \mathrm{s}^{-1}\right)$. The test was performed in laboratory conditions without a lubricant. The experimental data, obtained from the T-01M test device were processed by the NI DIADEM program.

The wear magnitude was measured at the wear trace created after the tribological test, by determining its width and depth on an Alicona Infinite Focus G5 optical measuring device. The wear trace was formed on the surface of the uncoated or coated test specimens by a sliding ball loaded by a normal force $\mathrm{F}_{\mathrm{N}}(5 \mathrm{~N}, 10 \mathrm{~N}$, and $15 \mathrm{~N}$ ), (Fig. 3).

After applying a thin Sucaslide DLC coating on the base material, scratch tests were performed to evaluate the adhesion of the coating to the base material. The scratch tests were performed on a Bruker UMT ${ }^{\circledR}$ device, with a Rockwell standard diamond tip, at a maximum load of $F_{N}=60 \mathrm{~N}$ in a length of $6 \mathrm{~mm}$. The scratch tester was connected to the computer via a control device. The adhesive-cohesive properties were evaluated from the morphology of scratches and the graphical recording of the acoustic emission signal, AE; the coefficient of friction (COF) depended on the load value and the optical image [16]. Three tests were performed for each specimen, to minimize the effect of local defects that could affect the results of the adhesive layer assessment. Measurements of the mechanical properties, hardness $\mathrm{H}_{\mathrm{IT}}$ and elastic modulus $\mathrm{E}_{\mathrm{IT}}$, were carried out on the heat-treated base material and the Sucaslide DLC coating. The nano-indentation measurements were performed by an Anton Paar NHT ${ }^{\circledR}$ Nanoindentation Tester, with a standard Berkovich ${ }^{\circledR}$ diamond tip. The indentation matrix was $3 \times 3$. Nine measurements were made on each specimen. The maximum load for each measurement was chosen so that the maximum penetration depth in the coating did not exceed $10 \%$ of its supposed thickness value $[17,18]$.

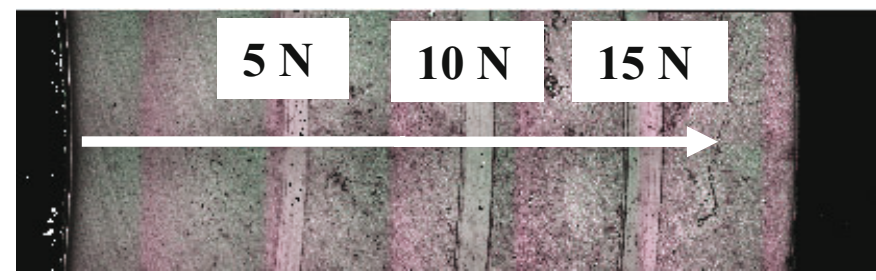

Fig. 3 The principle of measuring the magnitude of wear on the Alicona device 


\section{Results and discussion}

Results of the qualitative and the quantitative chemical analysis including the average hardness of the experimental material after heat treatment are listed in Table 1. The average hardness value of the experimental material after heat treatment was $63 \mathrm{HRC}$, while the hardness of the Sucaslide coated test specimens was 61 HRC. The decrease in the HRC hardness value was due to the coating procedure that lasted for 6 hours at a temperature of $200{ }^{\circ} \mathrm{C}$.

Table 1 Chemical composition (in wt. \%) and hardness (HRC) of the experimental material

\begin{tabular}{cccccccccc}
\hline $\mathrm{C}$ & $\mathrm{Si}$ & $\mathrm{Mn}$ & $\mathrm{P}$ & $\mathrm{S}$ & $\mathrm{Cr}$ & $\mathrm{Mo}$ & $\mathrm{Ni}$ & $\mathrm{Fe}$ & HRC \\
\hline 1.226 & 0.363 & 0.502 & 0.003 & 0.0033 & 1.38 & 0.072 & 0.195 & Bal. & 63 \\
\hline
\end{tabular}

The base material microstructure after heat treatment is shown in Fig. 4 and Fig. 5. The microstructure consisted of low-tempered martensite, evenly distributed carbides $(\mathrm{Fe}, \mathrm{Cr})_{3} \mathrm{C}$ and residual austenite (content of $6.30 \pm 0.90 \mathrm{wt} . \%$ ). The Sucaslide DLC coating deposited on the base material is shown in Fig. 6. After the deposition of the Sucaslide coating, the specimens were etched with $0.5 \%$ Nital and the quality of the coating was verified. The coating showed no signs of porosity.

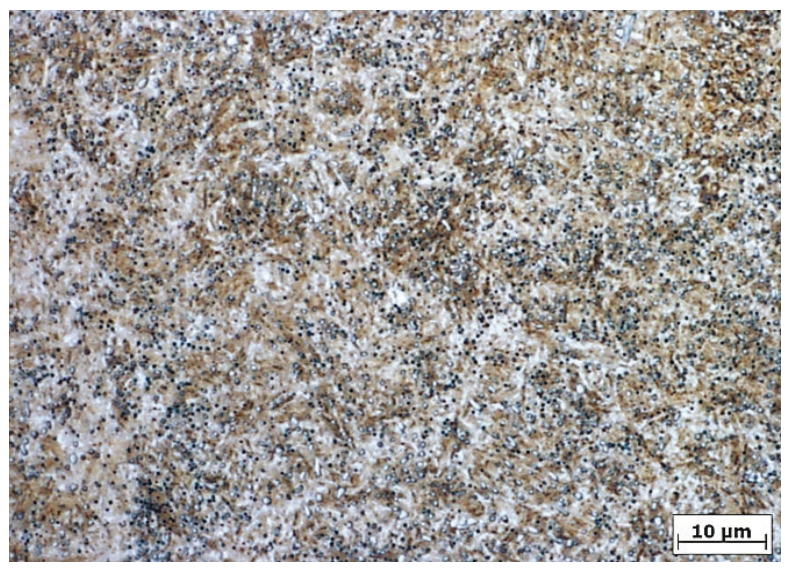

Fig. 4 Specimen microstructure: base material after heat treatment, etched in picric acid, optical microscopy
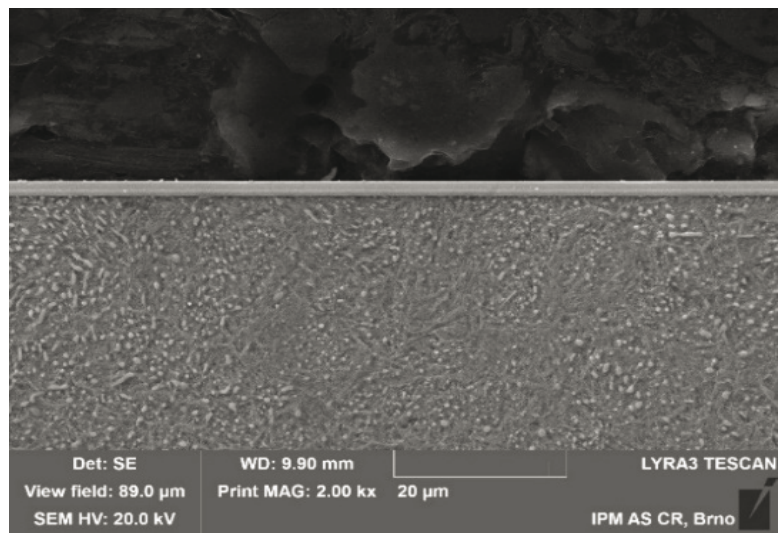

(a)

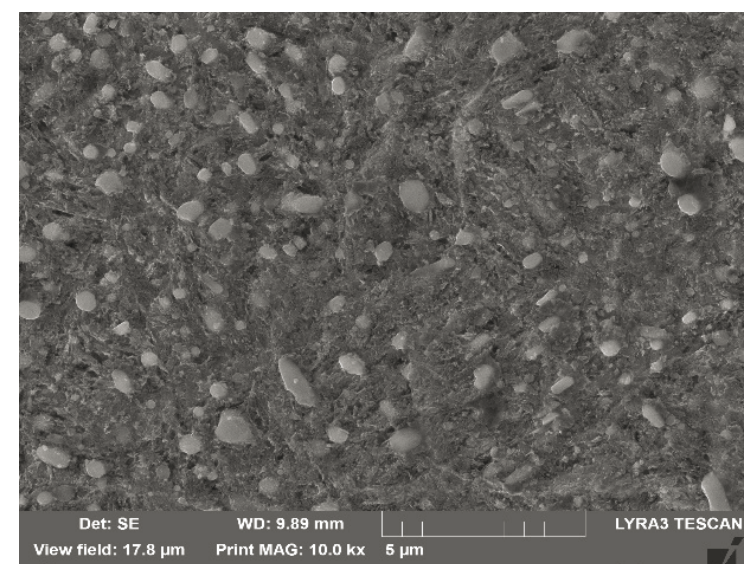

Fig. 5 Specimen microstructure: base material after heat treatment, etched in picric acid, SEM

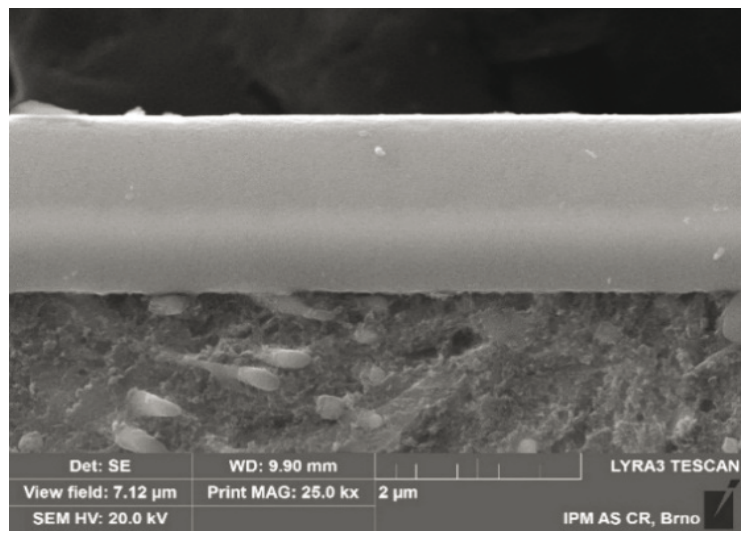

(b)

Fig. 6 Sucaslide DLC coating deposited on the base material, etched in $0.5 \%$ Nital, SEM:

a) general view, b) detail 
The measured values of coefficients of friction of the tested tribological pair, i.e. the base material vs. the Sucaslide DLC coating (referred to as the Sucaslide pair), are shown in Table 2. For comparison, the results of the reference pair, i.e. the base material versus the base material, are given in Table 3. Both sets of results are graphically illustrated and compared in Fig. 7.

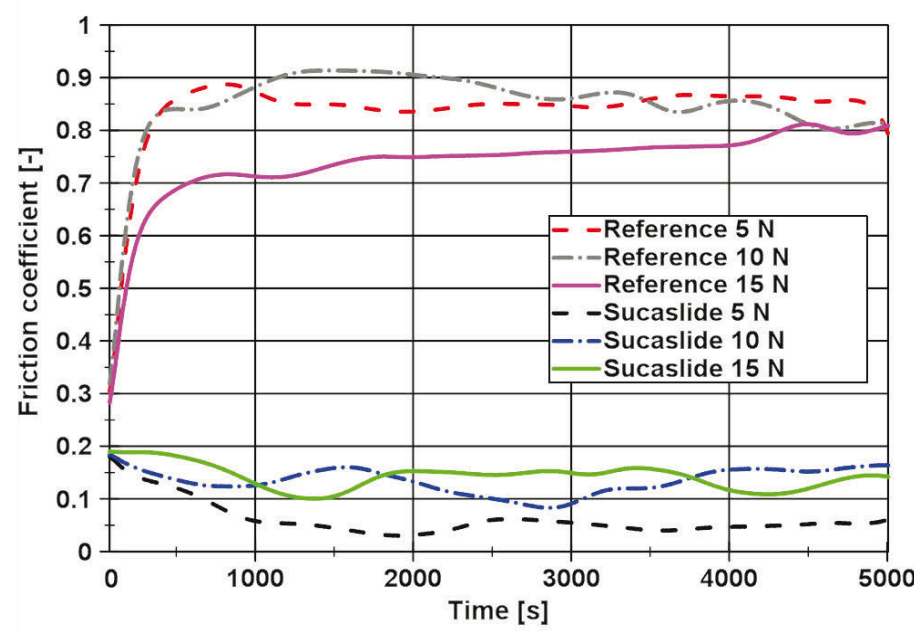

Fig. 7 Comparison of the friction coefficient of the Sucaslide pair and the reference pair: all loads $\left(\mathrm{F}_{\mathrm{N}}=5,10\right.$, and $\left.15 \mathrm{~N}\right)$

The values of the friction coefficient, given in Tables 2 and 3, are the average values of the three measurements made for each load. The friction coefficients of the reference pair at all three tested loads $\left(\mathrm{F}_{\mathrm{N}}=5 \mathrm{~N}, \mathrm{~F}_{\mathrm{N}}=10 \mathrm{~N}, \mathrm{~F}_{\mathrm{N}}=15 \mathrm{~N}\right)$ exhibited relatively high values (the average value was 0.799 ).

Table 2 Measured values of the coefficient of friction of the Sucaslide pair

\begin{tabular}{ccccc}
\hline Load $F_{\mathrm{N}}[\mathrm{N}]$ & \multicolumn{3}{c}{ Coefficient of friction [-] } & $\begin{array}{c}\text { Average coefficient } \\
\text { of friction [-] }\end{array}$ \\
\cline { 2 - 5 } & 1 & 2 & 3 & 0.060 \\
\hline 5 & 0.105 & 0.052 & 0.025 & 0.128 \\
\hline 10 & 0.18 & 0.114 & 0.091 & 0.142 \\
\hline 15 & 0.179 & 0.144 & 0.103 & 0.110 \\
\hline
\end{tabular}

Table 3 Measured values of the coefficient of friction of the reference pair

\begin{tabular}{ccccc}
\hline \multirow{2}{*}{ Load $F_{\mathrm{N}}[\mathrm{N}]$} & \multicolumn{3}{c}{ Coefficient of friction [-] } & $\begin{array}{c}\text { Average coefficient } \\
\text { of friction [-] }\end{array}$ \\
\cline { 2 - 5 } & 1 & 2 & 3 & 0.855 \\
\hline 5 & 0.907 & 0.809 & 0.850 & 0.801 \\
\hline 10 & 0.958 & 0.651 & 0.794 & 0.741 \\
\hline 15 & 0.754 & 0.746 & 0.725 & 0.799 \\
\hline
\end{tabular}

The coefficients of friction of the Sucaslide pair exhibited much lower values, compared to the reference pair; the specific average value was 0.110 , i.e. almost 7.3 times lower. The Sucaslide coating applied to the base material shows excellent friction properties, even in the absence of a lubricant. The EDX analysis showed that the Sucaslide DLC coating consists 
mainly of carbon and chromium, see Figure 8 . The high contents of carbon and chromium ensure the high hardness of the coating $\left(\mathrm{H}_{\mathrm{IT}} \approx 20 \mathrm{GPa}\right)$. Carbon and chromium form a super crystal lattice with strong bonds [19].
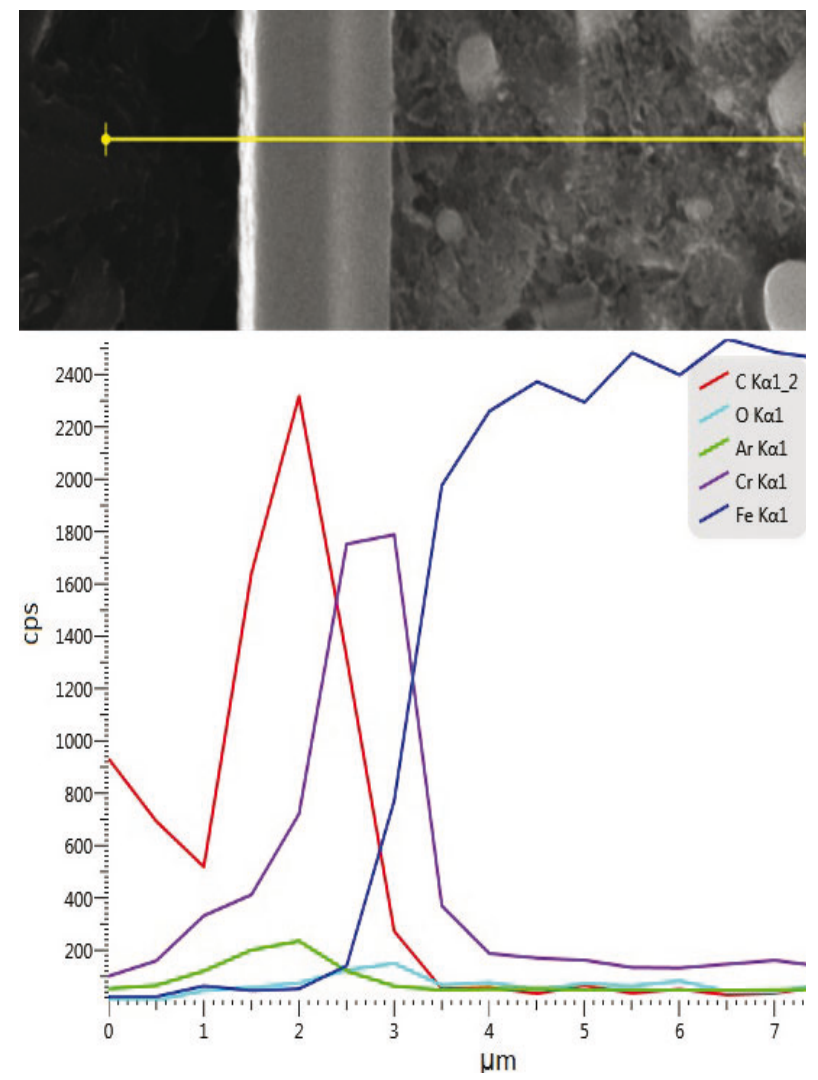

Fig. 8 The EDX analysis of the Sucaslide DLC coating

The wear results of the base material and the Sucaslide DLC coating, including the primary profile values of specimens, are shown in Fig. 9 and Fig. 10 and listed in Table 4. Here, $P_{a}$ is the average height of a profile, $P_{q}$ is the root-mean-square height of a profile, $P_{z}$ is the mean peak-to-valley height of the primary profile, and $R_{z}$ is the mean peak-to-valley height of the roughness profile. The results definitely prove the greater magnitude of wear of the reference specimens than that of the Sucaslide coated specimens. The wear depth detected on the surface of the reference specimen, at the location of the trace, reached a maximum value of $5.80 \mu \mathrm{m}$. The sample with the Sucaslide DLC coating exhibited a maximum wear value of $2.43 \mu \mathrm{m}$. In addition, from the evaluation of the wear trace width, one can see that several times higher values were obtained for the reference specimens than for the specimens with the Sucaslide DLC coating, in all loading regimes (Figures 9b and 10b).

Table 4 Experimental results of wear of the base material and the Sucaslide DLC coating

\begin{tabular}{ccccc}
\hline Sample & \multicolumn{4}{c}{ Parameters } \\
\cline { 2 - 5 } & $P_{\mathrm{a}}[\mu \mathrm{m}]$ & $P_{\mathrm{q}}[\mu \mathrm{m}]$ & $P_{\mathrm{z}}[\mu \mathrm{m}]$ & $R_{\mathrm{z}}[\mu \mathrm{m}]$ \\
\hline Base material & 1.138 & 1.498 & 5.80 & 2.9 \\
\hline Sucaslide & 0.415 & 0.516 & 2.43 & 1.6 \\
\hline
\end{tabular}




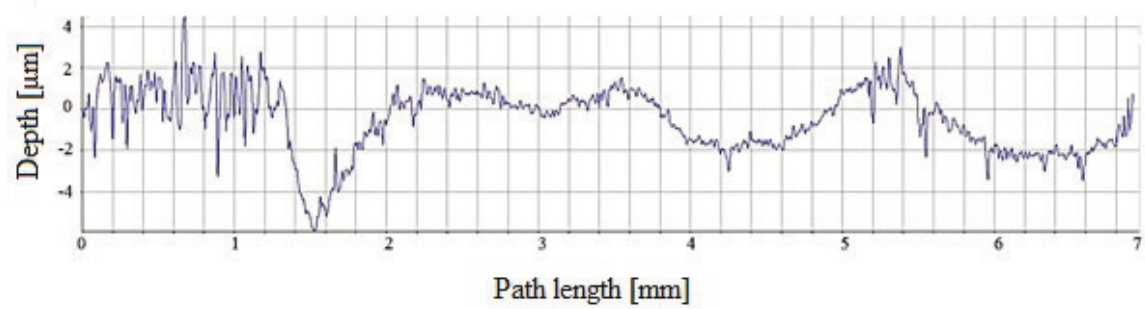

(a)

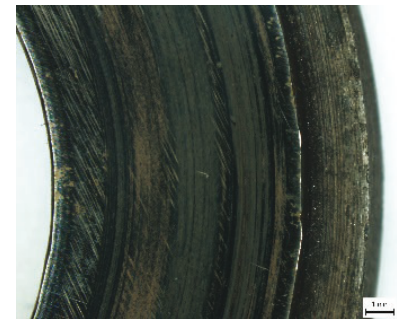

(b)

Fig. 9 Base material wear, a) primary profile, b) specimen appearance

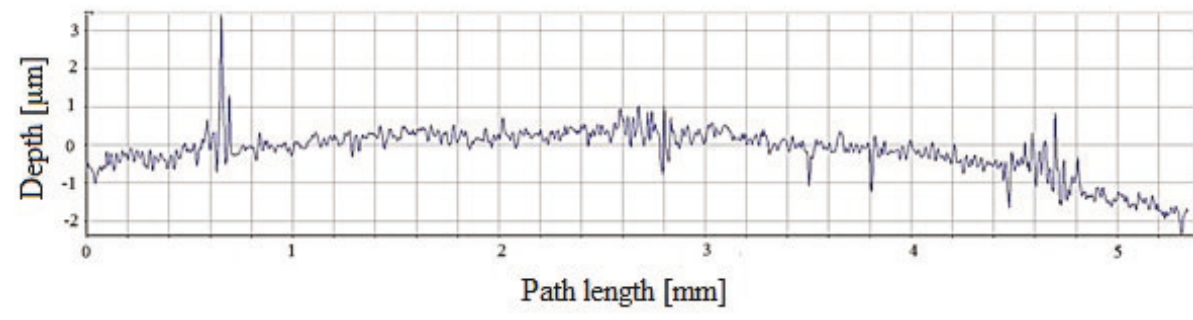

(a)

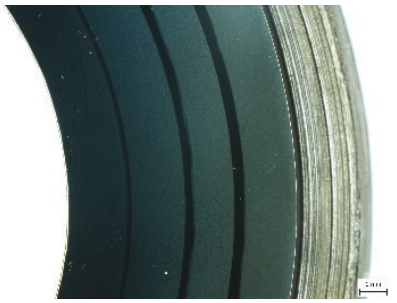

(b)

Fig. 10 Sucaslide DLC coating wear, a) primary profile, b) specimen appearance

The results of measuring the adhesion of the Sucaslide DLC coating are shown in Fig. 11. The acoustic emission record, AE, depending on the normal load $\mathrm{F}_{Z}$ applied by the indenter, is shown in Fig. 11a. The significant increase in the acoustic emission signal is determined by the adhesion-resistant failure of the Sucaslide DLC coating. The acoustic emission values found in the measurement No. 001 were recorded at a normal force of $\mathrm{F}_{\mathrm{Z}} \sim 27 \mathrm{~N}$. In the measurement No. 002, a significant increase in the value of the acoustic emission signal was recorded at a normal force load of $\mathrm{F}_{Z} \sim 42 \mathrm{~N}$. The calculated mean value of the occurrence of first cracks was $F_{Z}=33 \mathrm{~N}$. According to the authors of studies $[2,3]$, the protection of elements under mechanical stress is satisfactory for coatings used in operating conditions if the values of adhesion force are $\mathrm{F}_{\mathrm{Z}} \leq 45 \mathrm{~N}$.

The trace surface morphology after scratch tests is presented in Fig. 12. Assessment of the results shown in Fig. 11b and Fig. 12 shows that a significant increase in the coefficient of friction is associated with the delamination of the Sucaslide DLC coating and the penetration of the indenter tip into the coating all the way to the base material. For the specimen 001, the friction coefficient began to increase at a loading force of $\mathrm{F}_{Z} \sim 51 \mathrm{~N}$, for the specimen 002 at $\mathrm{F}_{Z} \sim 47 \mathrm{~N}$, and for the specimen 003 at $\mathrm{F}_{Z} \sim 48 \mathrm{~N}$. The average critical force $\mathrm{F}_{Z}$ required for breaking the Sucaslide coating was determined as $\mathrm{F}_{\mathrm{Z}}=48 \mathrm{~N}$. 


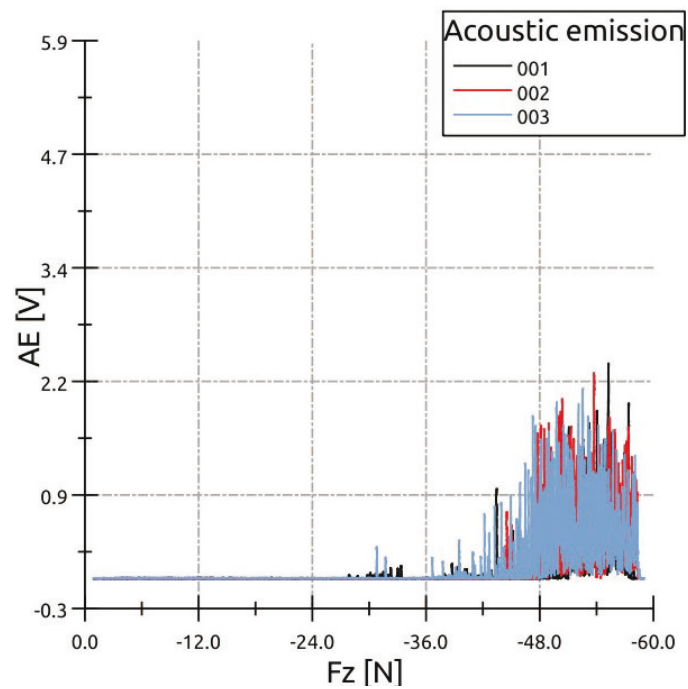

(a)

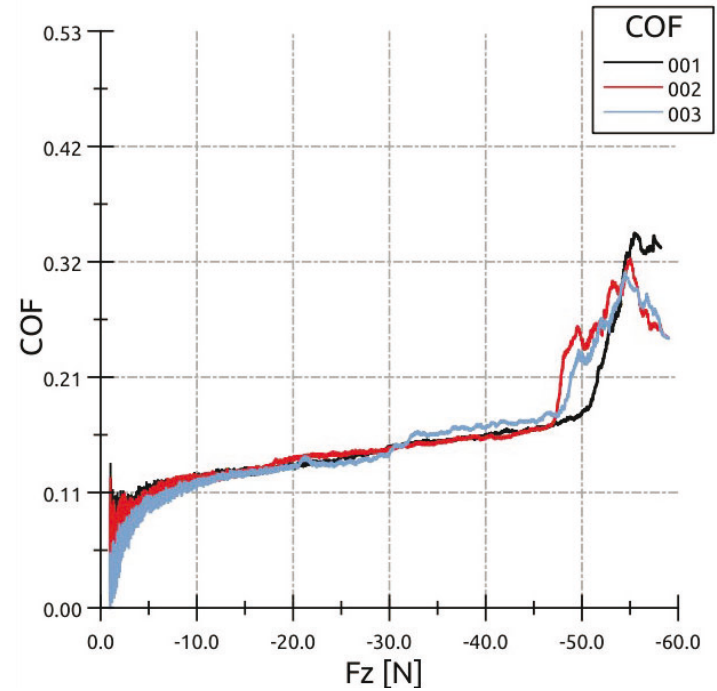

(b)

Fig. 11 Results of measurements of the Sucaslide DLC coating adhesion: a) acoustic emission, b) coefficient of friction

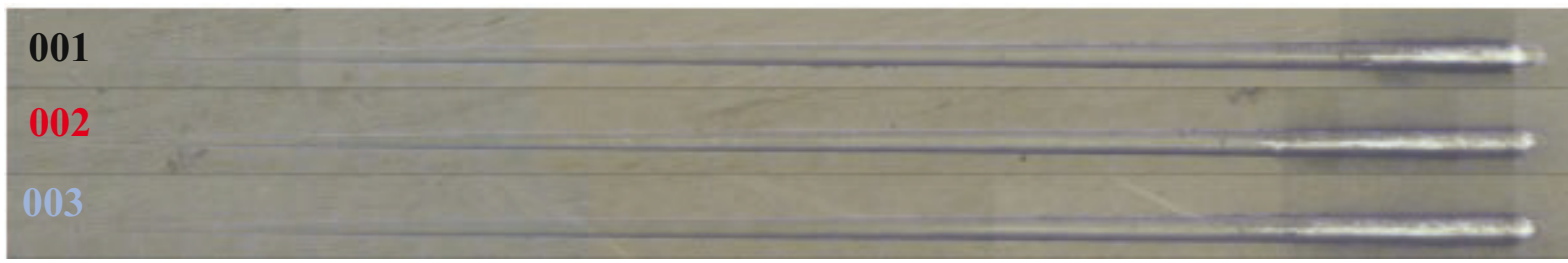

Fig. 12 Morphology of traces on the Sucaslide DLC coating after the scratch test

Results of determining the mechanical properties of the base material and the Sucaslide DLC coating by the nano-indentation method are shown in Tables 5 and 6. From these results it is clear why the Sucaslide DLC coating possesses excellent friction properties. The coating has a very high $\mathrm{H}_{\mathrm{IT}}$ hardness values, almost $20 \mathrm{GPa}(\approx 2000 \mathrm{HV} 10)$. In addition to high hardness, it has a high value of the elasticity modulus, $\mathrm{E}_{\mathrm{IT}}=178 \mathrm{GPa}$, as well. The high hardness of the coating ensures low values of the friction coefficient at higher contact pressures, while it simultaneously increases its wear resistance.

Table 5 Results of mechanical properties of the base material

\begin{tabular}{ccccccccccc}
\hline \multirow{2}{*}{ Parameter } & \multicolumn{10}{c}{ Measurement number } \\
\cline { 2 - 11 } & 1 & 2 & 3 & 4 & 5 & 6 & 7 & 8 & 9 & Average \\
\hline $\mathrm{H}_{\mathrm{IT}}[\mathrm{GPa}]$ & 9.83 & 9.72 & 10.1 & 9.87 & 9.87 & 9.9 & 10.03 & 10.61 & 9.51 & $9.9 \pm 0.3$ \\
\hline $\mathrm{E}_{\mathrm{IT}}[\mathrm{GPa}]$ & 235.6 & 238.9 & 249.4 & 233.3 & 247 & 243 & 253.6 & 235.4 & 251.5 & $243 \pm 7$ \\
\hline
\end{tabular}

Table 6 Results of mechanical properties of the Sucaslide DLC coating

\begin{tabular}{ccccccccccc}
\hline & \multicolumn{8}{c}{ Measurement number } & \multirow{2}{*}{ Average } \\
\cline { 2 - 11 } & 1 & 2 & 3 & 4 & 5 & 6 & 7 & 8 & 9 & \\
\hline $\mathrm{H}_{\mathrm{IT}}[\mathrm{GPa}]$ & 20.3 & 21.6 & 20.7 & 21.5 & 21.1 & 18.6 & 18.6 & 18.1 & 17.6 & $19.8 \pm 1.6$ \\
\hline $\mathrm{E}_{\mathrm{IT}}[\mathrm{GPa}]$ & 197 & 192 & 193 & 188 & 175 & 176 & 175 & 152 & 156 & $178 \pm 16$ \\
\hline
\end{tabular}




\section{Conclusions}

Based on the experimental work carried out to determine the tribological properties of the Sucaslide DLC coating applied to stainless low-alloy steel, it is possible to state the following:

- The applied Sucaslide DLC coating of a thickness of 1.5 to $2.0 \mu \mathrm{m}$ is characterized by excellent adhesion without signs of porosity;

- The $\mathrm{H}_{\mathrm{IT}}$ hardness of the Sucaslide DLC coating verified by the nano-indentation method is high, i.e. $19.8 \mathrm{GPa}$;

- The application of the coating did not significantly reduce the hardness of the base (substrate) material, i.e. stainless low-alloy steel (from $63 \mathrm{HRC}$ before to $61 \mathrm{HRC}$ after coating);

- Values of the coefficient of friction of the Sucaslide DLC coating are very low $(\approx 0.110)$, compared to the values of the coefficient of friction of the base (substrate) material, i.e. stainless low-alloy steel $(\approx 0.799)$;

- On specimens coated with the Sucaslide DLC coating, no wear was noted after tribological tests, while significant wear was noted on specimens of the base material, up to a maximum depth of $5.80 \mu \mathrm{m}$;

- The Sucaslide DLC coating is characterized by good adhesion properties;

- The Sucaslide DLC coating is characterized by very good sliding and abrasionresistance properties, as well;

- The Sucaslide DLC coating can be recommended for application on stainless lowalloy steel used in the bearing industry;

- The benefits are an increase in the service life, as well as in the reliability and safety of components and equipment in operation.

\section{Acknowledgements}

This research was partially financially supported by projects VEGA 1/0951/17, KEGA 012ŽU-4/2019 and ITMS2014+NFP313010T426 "Research and development activities of Žilina University in Žilina for the 21 st century industry in the field of materials and nanotechnologies" financed by the European regional development fund and the Slovak state budget.

\section{REFERENCES}

[1] https://www.machinerylubrication.com/Read/664/wear-bearings-gears

[2] Drabik, M.; Truchlý, M.; Ballo, V.; Roch, T.; Kvetková, L.; Kúš, P. Influence of substrate material and its plasma pretreatment on adhesion and properties of WC/a-C:H nanocomposite coatings deposited at low temperature, Surface and Coatings Technology 2018, 333, 138-147.

https://doi.org/10.1016/j.surfcoat.2017.10.081

[3] Drábik, M.; Ballo, V.; Truchlý, M.; Frkáň, J.; Roch, T.; Kvetková, L.; Satrapinskyy, L.; Kúš, P. Influence of plasma pretreatment on the performance of industrial tungsten carbide coatings deposited at low temperature on 100Cr6 bearing steel substrates, Surface and Coatings Technology 2016, 293, 2-9. https://doi.org/10.1016/j.surfcoat.2016.01.035

[4] Fabian, P.; Zrak, A. Evaluation of selected properties of steel $100 \mathrm{Cr} 6$ at different ways of heat treatment. Manufacturing Technology 2016, 16 (4), 687-691. https://doi.org/10.21062/ujep/x.2016/a/1213$2489 / \mathrm{mt} / 16 / 4 / 687$

[5] Haque, T.; Morina, A.; Neville, A.; Kapadia, R.; Arrowsmith, S. Effect of oil additives on the durability of hydrogenated DLC coating under boundary lubrication conditions, Wear 2009, 266, (1-2), 147-157. https://doi.org/10.1016/j.wear.2008.06.011 
[6] Keunecke, M.; Bewilogua, K.; Becker, J.; Gies, A.; Grischke, M. CrC/a-C:H coatings for highly loaded, low friction applications under formulated oil lubrication, Surface and Coatings Technology 2012, 207, 270-278. https://doi.org/10.1016/j.surfcoat.2012.06.085

[7] Wen-Hsien Kao. The tribological properties of Zr-C:H coatings deposited on AISI M2 substrate, Wear 2008, 264 (3-4) 368-373, https://doi.org/10.1016/j.wear.2007.01.117

[8] Hadzima, B.; Pastorek, F.; Borko, K.; Fintová, S.; Kajánek, D.; Bagherifard, S.; Gholami-Kermanshahi, M.; Trško, L.; Pastorková, J.; Brezina, J. Effect of phosphating time on protection properties of hurealite coating: Differences between ground and shot peened HSLA steel surface, Surface and Coatings Technology 2019, 375, 608-620, https://doi.org/10.1016/j.surfcoat.2019.07.056

[9] Brezinova, J.; Draganovska, D.; Guzanova, A.; Balog, P.; Vnas, J. Influence of the hard facing welds structure on their wear resistance. Metals 2016, 6 (2) 1-12. https://doi.org/10.3390/met6020036

[10] Cselle, T.; Coddet, O.; Holubar, P.; Jilek, M.; Jilek, J.; Luemkemann, A.; Morstein, M. Počítačová simulace růstu PVD povlaků a nová řada trojvrstvých povlaků. MM Průmyslové spectrum 2008, 9, 136137 (In Czech)

[11] Jakubeczyova, D.; Hagarova, M.; Faberova, M. Study of PVD Thinn Layers Applied on Tool PM Steel. 16th International Metallurgical \& Material Conference, Metal 2017, 133 (1-7) Hradec nad Moravicí, Czech Republic,

[12] Rincón, C.; Zambrano, G.; Carvajal, A.; Prieto, P.; Galindo, H.; Martínez, E.; Lousa, A.; Esteve, J. Tungsten carbide / diamond-like carbon multilayer coatings on steel for tribological applications, Surface and Coatings Technology 2001, 148, 277-283. https://doi.org/10.1016/s0257-8972(01)01360-3

[13] Nouvellon, C.; Belchi, R.; Libralesso, L.; Douhéret, O.; Lazzaroni, R.; Snyders, R.; Thiry, D. WC/C:H films synthesized by an hybrid reactive magnetron sputtering/ Plasma Enhanced Chemical Vapor Deposition process: An alternative to Cr (VI) based hard chromium plating, Thin Solid Films 2017, 630, 79-85. https://doi.org/10.1016/j.tsf.2016.09.002

[14] Jean, M.-D.; Liu, CH.W.; Yang, P.H.; Ho, W.H. Optimization of Wear Behavior of DLC Coatings through Optimization of Deposition Conditions, Materials Science 2020, 26(3), 269-280, http://dx.doi.org/10.5755/j01.ms.26.3.22101

[15] http://www.tribologia.org/ptt-old/inst/rad/T-01M.pdf

[16] Dekys, V. Condition monitoring and fault diagnosis. Procedia Engineering 2017, 177, 502-509 Kottfer, D.; Štěpánek, I.; Mrva, P.; Dzedzina, R. Hodnotenie adhéznych vlastností tenkých PVD povlakov vrypovou indentáciou. Transfer inovácií 2009, 15 64-68 (In Slovak). https://doi.org/10.1016/j.proeng.2017.02.252

[17] Oliver, W. C.; Pharr, G. M. Measurement of hardness and elastic modulus by instrumented indentation: Advances in understanding and refinements to methodology. Journal of Materials Research 2004, 16 (1), 3-20. https://doi.org/10.1557/jmr.2004.19.1.3

[18] Kelly, M. J. Encyclopedia of Physical Science and Technology (Third Edition), Academic Press 2003, eBook ISBN 9780080917955

Submitted: $\quad 05.6 .2020$

Accepted: $\quad 21.01 .2021$
Martin Vicen

martin.vicen@fstroj.uniza.sk

Jozef Bronček

Otakar Bokůvka

Faculty of Mechanical Engineering,

University of Žilina, Žilina, Slovakia

Ružica Nikolić

Research Centre, University of Žilina,

Žilina, Slovakia

Norbert Radek

Faculty of Mechatronics and Machine

Design, Kielce University of Technology,

Kielce, Poland 